FOLIA POMERANAE UNIVERSITATIS TECHNOLOGIAE STETINENSIS

Folia Pomer. Univ. Technol. Stetin., Oeconomica 2018, 352(94)1, 59-68

Maciej OESTERREICH

\title{
FORECAST VALUES OF HDI COMPONENTS FOR EUROPEAN COUNTRIES FOR 2018-2022
}

Department of Applied Mathematics in Economics, West Pomeranian University of Technology in Szczecin, Poland, ul. Klemensa Janickiego 31, 71-270 Szczecin, ORCID: 0000-0003-4750-3636 e-mail: moesterreich@zut.edu.pl

Summary. The article presents the forecast values of the four components of the human development index that pertain to three areas of life, namely health, education and income, for 42 European countries, covering the period from 2018 to 2022, with a focus on Poland. The Holt model was used as a predictor. The results suggest that the social and economic dimensions will continue to improve in most of the analyzed countries. Statistical data used were derived from the Human Development Reports. The calculations were made using the R package.

Key words: HDI components, forecasts, Europe, Poland.

\section{INTRODUCTION}

The Human Development Index (HDI) is a useful tool for assessing both the economic and social development of countries. Therefore, it has been used by the United Nations Development Programme (UNAP) since 1993 in its annual reports on 188 countries (Stanton 2007). Its value is determined based on four attributes describing three main areas of life: one referring to health, two to education, and a fourth one to income per capita. These attributes are:

- life expectancy (in years);

- mean years of schooling received by persons aged 25 or older (in years);

- expected years of schooling for children beginning their education (in years);

- gross national income per capita (PPP ${ }^{1}$ in USD - 2011).

The statistical data relating to these variables were mainly obtained from the statistical offices of the individual countries covered by the study. They encompass the year prior to the year of study, except for the information on the gross national income per capita which was derived from reports by the International Comparison Program. The methodological aspects of HDI determinations are presented in the works of Anand and Sen (1994; UNPD 2017).

As the value of the $\mathrm{HDI}$ is a resultant of the values of its components, the main objective of this paper was to construct and analyze the forecast values of the four HDI components for 42 European countries covering the temporal scope from 2018 to 2022, with a focus on Poland.

Due to the nature of the components concerned, the papers to be found in literature mainly concentrate on the construction of life expectancy forecasts. Here, the papers authored by Lee (2003), Torri and Vaupel (2012), Kontis et al. (2017) and Foreman et al. (2018) should be referenced as some examples, and statistical offices' reports, including the "Population forecast for 2014-2050" (Gus 2014), should be mentioned, as well.

\footnotetext{
${ }_{1}^{1}$ Purchasing Power Parities are such changes to FX rates that equalize the value of the purchasing power by eliminating price level differences between countries (OECD 2012).
} 


\section{RESEARCH PROCEDURE}

The forecasts for the HDI components were determined for the period from 2018 to 2022 for 42 European countries. The choice of the temporal scope for the forecasts resulted from the availability of statistical data. The data obtained from the website of the United Nations Development Programme (UNDP) ${ }^{2}$ described the four components of the human development index for the period from 1990 to 2017 for each of the countries. In the course of our analysis of the statistical material collected it was discovered that there were gaps in the case of several countries in respect of both the education-related components:

- mean years of schooling: in the case of Andorra, Belarus, Bosnia and Hercegovina, Macedonia and Montenegro, for which the number of missing observations amounted to $10,5,10,10$ and 3 , respectively;

- expected years of schooling: in the case of Bosnia and Hercegovina, Lichtenstein and Montenegro, for which the number of missing observations amounted to 10,10 and 13 , respectively.

Since these gaps only occurred in the initial stages of the time series, they were omitted when constructing the predictors.

The forecast components demonstrated variable dynamics, the two-parameter Holt model was therefore used as a predictor (Zeliaś et al. 2003, pp. 148-149; Holt 2004):

$$
\left\{\begin{array}{l}
\hat{y}_{1}=y_{1} \\
\hat{y}_{t}=\alpha y_{t}+(1-\alpha)\left(\hat{y}_{t-1}+c_{t-1}\right)
\end{array}\right.
$$

with:

$$
\left\{\begin{array}{l}
c_{1}=y_{2}-y_{1} \\
c_{t}=\beta\left(\hat{y}_{t}-\hat{y}_{t-1}\right)+(1-\beta) c_{t-1}
\end{array}\right.
$$

where:

$\hat{y}_{t}$ - assessment of trend value (smoothed value) over time $t$;

$\alpha$ - smoothing constant $(\alpha \in(0,1))$;

$c_{t}$ - smoothed value of the increment of trend value assessments over time $t$;

$\beta$ - smoothing constant $(\beta \in(0,1))$.

This model is characterized by a capacity to quickly adapt to changes in the forecast variables. Using this method, the forecasts were constructed along with the HoltWinters ${ }^{3}$ procedure from the package stats in the $\mathrm{R}$ environment.

\section{RESEARCH RESULTS}

\section{Life expectancy}

Figure 1 shows the changing average life expectancy values (LEaB) for 42 European countries and Poland over the period from 1990 to 2017 and the forecasts determined for the period from 2018 to 2022 .

\footnotetext{
2 http://hdr.undp.org/en

${ }^{3}$ http://stat.ethz.ch/R-manual/R-devel/library/stats/html/HoltWinters.html
} 


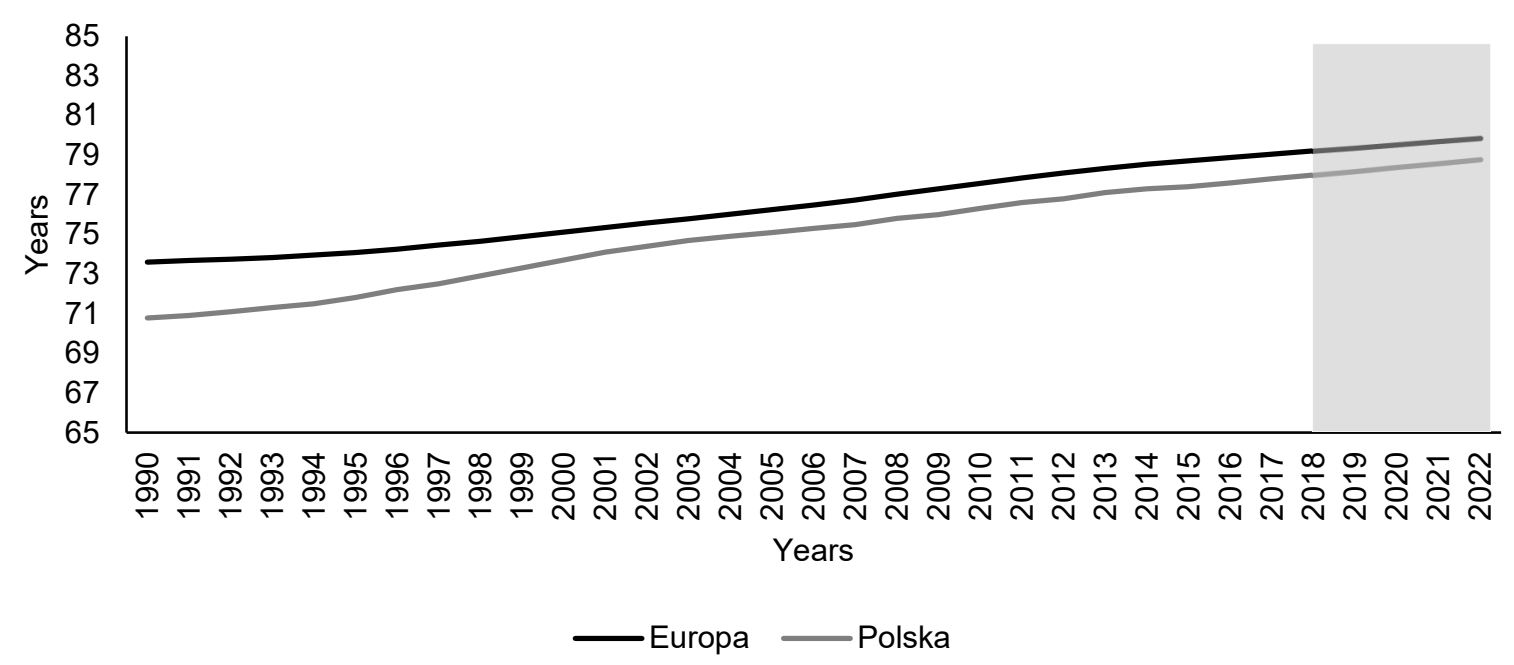

Fig. 1. Average life expectancy between 1990 and 2017 and the forecasts for 2018-2022 for 42 European countries and Poland Source: author's own study based on the UNDP data.

Between 1990 and 2017, the average life expectancy for 42 European countries increased from 73.6 to 79.04 years, i.e. by approx. $7.38 \%$. For Poland, this value was clearly lower but more dynamic at the same time, as it grew from 70.8 to 77.8 years, i.e. by $11.27 \%$.

The average life expectancy for the 42 European countries covered by this study in the forecast period (2018-2022) should keep growing to reach a level of 79.85 years. The average absolute annual increment over this period should be approx. 0.16 years and will be slightly lower than it was in the period immediately preceding the forecast horizon (from 2013 to 2017), which was 0.18 years.

Figure 2 presents, in a non-decreasing order, European countries according to their life expectancy in 2017 and the forecasts for 2022.

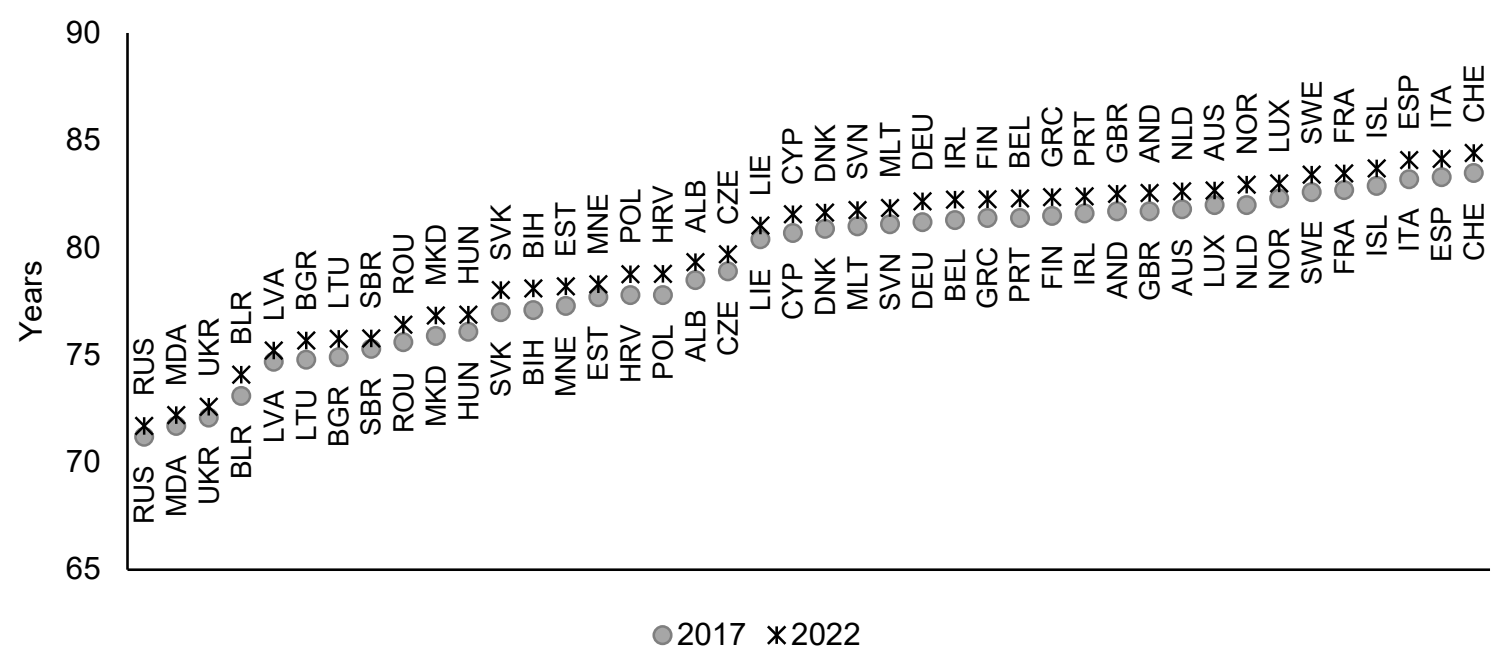

Fig. 2. European countries according to their life expectancy in 2017 and the forecasts for 2022 Source: author's own study based on the UNDP data.

The highest value of life expectancy in 2017 was observed for Switzerland, where it reached 83.5 years. Only slightly lower values were identified for Spain and Italy, with 83.3 and 83.2 years, respectively. The lowest level was found for Russia (71.2 years). For Poland, which 
ranked 26th, the level of this component was 5.7 years lower than for Switzerland and 6.6 years higher than that for Russia, reaching 77.8 years.

In 2022 , similarly to 2017 , the Swiss will live the longest ( 84.4 years), closely followed by Italians (84.2 years) and Spaniards (84.1 years), which is an increase of $0.92,0.96$ and 0.79 years, respectively, when compared to 2017 . The lowest forecast value of 71.7 years was determined (again) for Russia, with an increase of 0.5 years. For Poland, ranking 27th, the value of this component should increase by 0.98 years to reach 78.8 years. The highest growth in the value of this component between 2017 and 2022 is expected to take place in Slovakia (1.04 years), and the lowest for Serbia (0.48 years).

It should be pointed out that both in 2017 and 2022 as many as 23 out of the 42 studied countries demonstrated life expectancies exceeding 80 years. Most of these were from Western and Northern Europe. Such a district division may result from the lower levels of prosperity among the Central, Eastern and Balkan societies (cf. European Commission 2019), and therefore a lower quality of and accessibility to healthcare leading to higher mortality rates due to cardiovascular diseases (Eurostat 2018) and a lower quality of life (cf. Raczkowska 2016).

\section{Mean years of schooling received by persons aged 25 or older}

Due to the nature of the next two HDI components, mean years of schooling received by persons aged 25 or older (MYoS) and expected years of schooling for children beginning their education (EYOS), constructing forecasts for them was a more difficult task. The reason for this was that their situation is largely dependent on political decisions, which implies hardly predictable fluctuations.

Figure 3 shows the changing average values of the mean years of schooling received by persons aged 25 or older for Europe and Poland between 1990 and 2017 and the forecasts for 2018-2022.

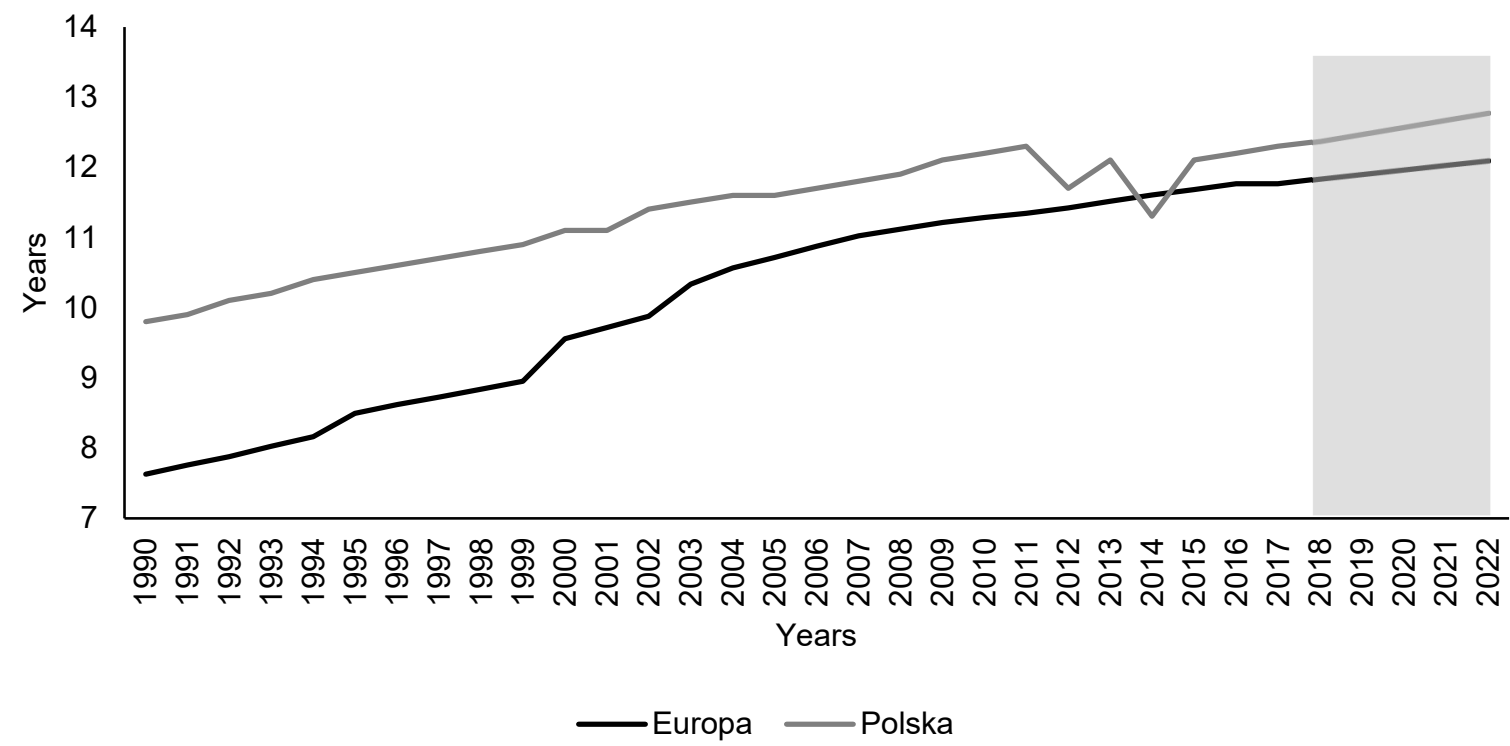

Fig. 3. Average mean years of schooling received by persons aged 25 or older between 1990 and 2017 and the forecasts for 2018-2022 for 42 European countries and Poland Source: author's own study based on the UNDP data. 
The average mean years of schooling in Europe between 1990 and 2017 grew from 7.6 to 11.8 years, i.e. by $54 \%$. For Poland, this component demonstrated a growing trend, as well, as it increased from 9.8 to 12.3 years, i.e. by $25.5 \%$. The year 2014 is particularly noteworthy, as it was the only one that saw the value being higher for Europe than for Poland.

Our analysis of the forecast average values of the mean years of schooling component for 2018-2022 shows that for Europe its value should increase by 0.33 years, i.e. to the level of 12.1 years. For Poland, the value is expected to rise to 12.8 in 2022, which is 0.47 more than in 2017. Figure 4 presents, in a non-decreasing order, European countries according to their mean years of schooling in 2017 and the forecasts for 2022.

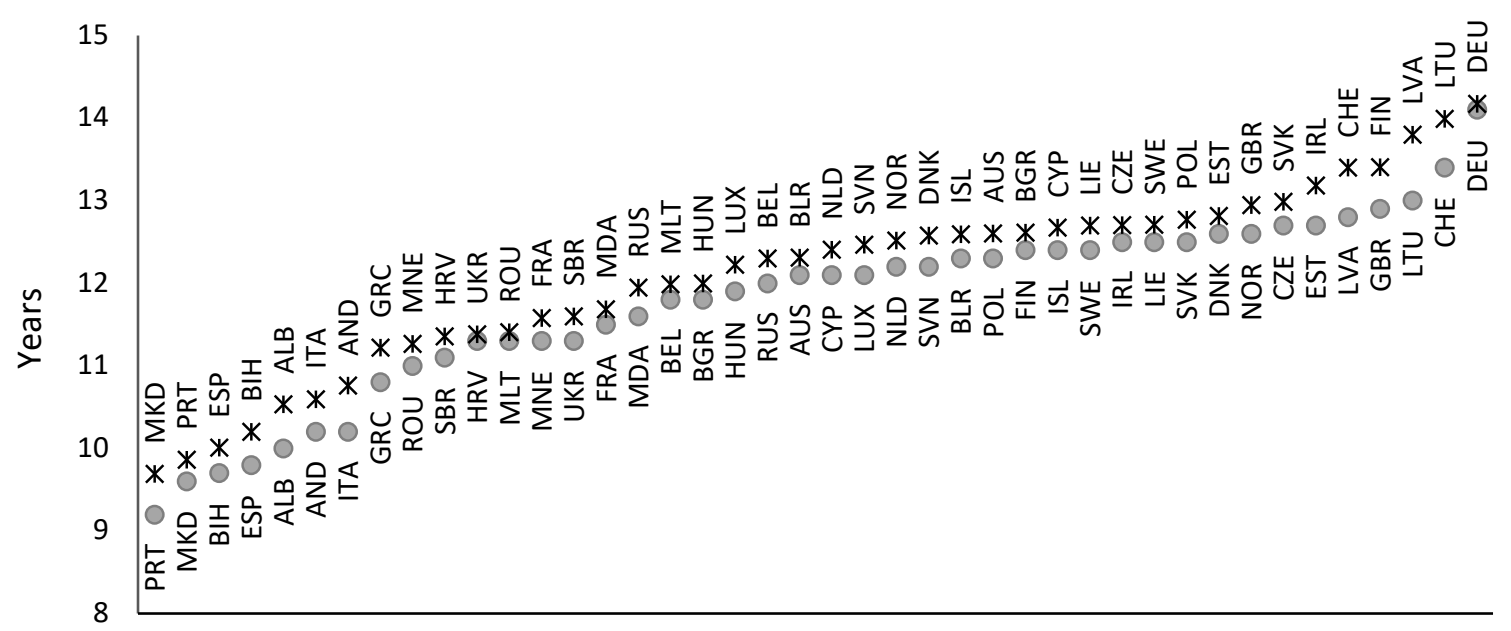

○ $2017 * 2022$

Fig. 4. European countries according to their mean years of schooling received by persons aged 25 or older in 2017 and the forecasts for 2022

Source: author's own study based on the UNDP data.

In 2017, persons aged 25 or older received the most years of schooling in Germany (14.1 years), Switzerland (13.4 years) and Lithuania (13 years), and the fewest in Portugal (9.2 years). Poland ranked 17th, with the value of this component amounting to 12.3, the same as for Belarus.

According to the forecasts, the longest-lasting education in 2022 will be offered in Germany (14.2 years), Lithuania (14 years) and Latvia (13.8 years), and the shortest-lasting one in Macedonia (9.7 years). As for Poland, the value of this component should reach 12.8 years, which ranks it $10^{\text {th }}$ in Europe.

Compared to the values in 2017, the component should increase the most in Finland, Latvia and Lithuania - by approx. 1 year. For four countries, namely Norway, Russia, Montenegro and Denmark, the forecasts expect the years of schooling to drop slightly (by less than 0.1 years).

\section{Expected years of schooling for children beginning their education}

Figure 5 shows the second of the educational components of the HDI: expected years of schooling for children beginning their education (EYoS) for Europe and Poland between 1990 and 2017 and the forecasts for 2018-2022. 


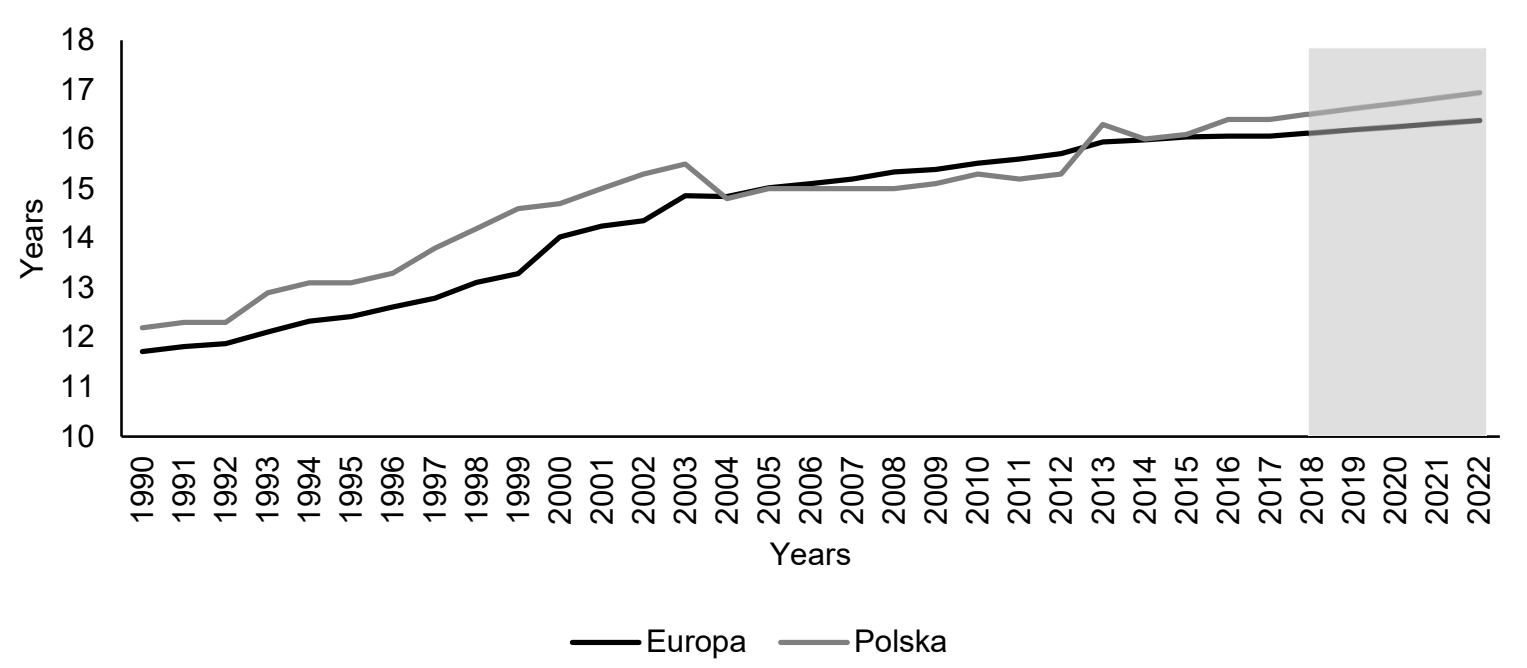

Fig. 5. Average expected years of schooling for children beginning their education between 1990 and 2017 and the forecasts for 2018-2022 for 42 European countries and Poland Source: author's own study based on the UNDP data.

The mean value of this component for European countries in the study period rose from 11.7 (1990) to 16.1 years (2017), i.e. by more than $37 \%$. In the same period for Poland, the value grew from 12.2 to 16.4 years, i.e. by $34.4 \%$. Of particular interest in this period are the years from 2004 to 2012, where the value of the expected years of schooling component for Europe was higher than that for Poland.

An analysis of the forecasts for the expected years of schooling received by children beginning their education for 2018-2022 shows that the value of this component should increase by 0.32 years to reach 16.4 years. Poland is expected to reach the level of 16.9 years in 2022, which is an increase of 0.54 years as compared to 2017. Figure 6 presents, in a non-decreasing order, European countries according to their expected years of schooling in 2017 and the forecasts for 2022.

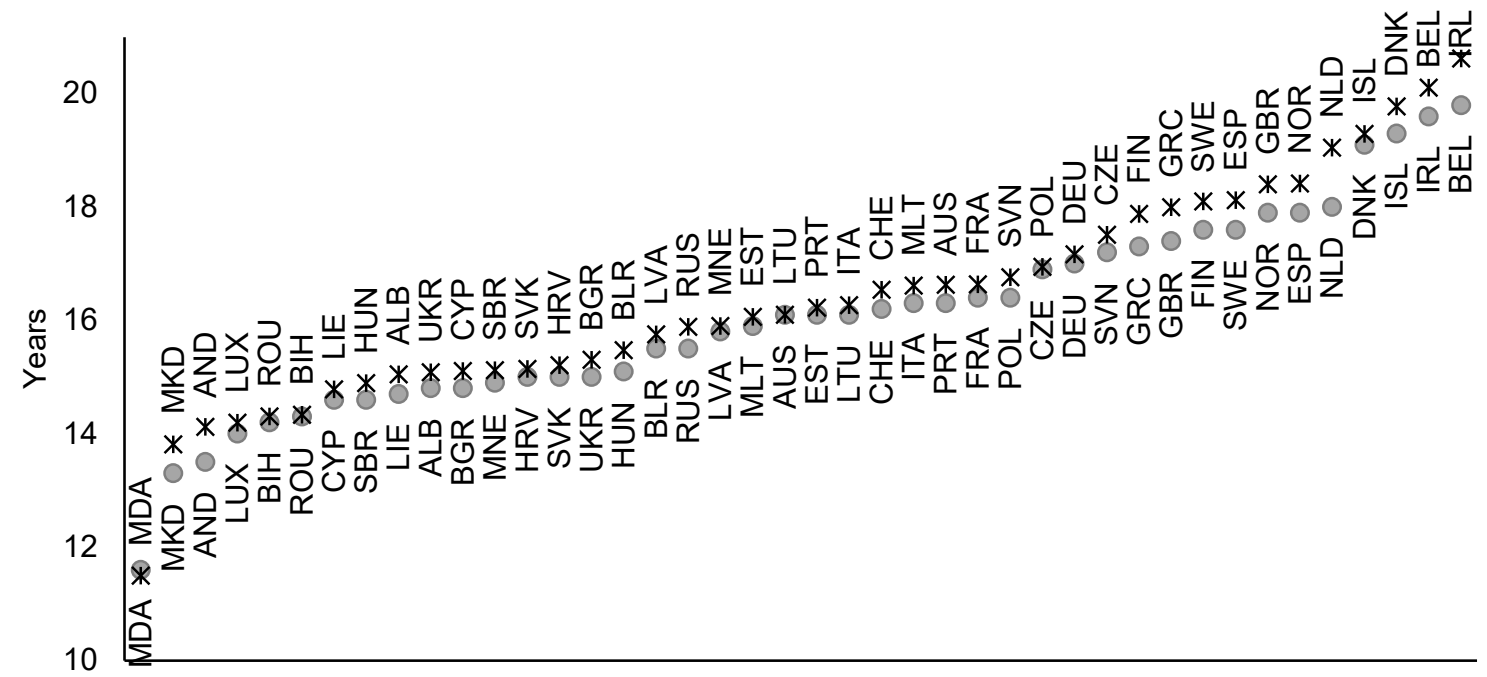

$2017 * 2022$

Fig. 6. European countries according to their expected years of schooling for children beginning their education in 2017 and the forecasts for 2022

Source: author's own study based on the UNDP data. 
The highest values of the expected years of schooling for children beginning their education in 2017 were demonstrated by Belgium (19.8 years), Ireland (19.6 years) and Iceland (19.3 years). The shortest period of education was offered in Moldavia (11.6 years). Poland, with a value of 16.6 years, ranked $15^{\text {th }}$.

In 2022, the highest value of the analyzed component should be demonstrated by Ireland (20.62 years), followed by Belgium (20.1 years) and Denmark (19.8 years). The shortest-lasting education, similarly to 2017 , will be offered to the inhabitants of Moldavia (11.5 years). Poland, with the forecast value of 19.4 years, should rank $14^{\text {th }}$ in Europe.

The highest increase in the value of this component between 2017 and 2022 is forecast for the Netherlands and Ireland, amounting to approx. 1 year. For 10 countries, the growth is expected to be negative, while its highest absolute value of -0.44 is anticipated for Slovenia.

\section{National income per capita}

Figure 7 presents the changing values of the mean gross national income (GNI) per capita for 42 analyzed European Countries and Poland between 1990 and 2017 and the forecasts for 2018-2022.

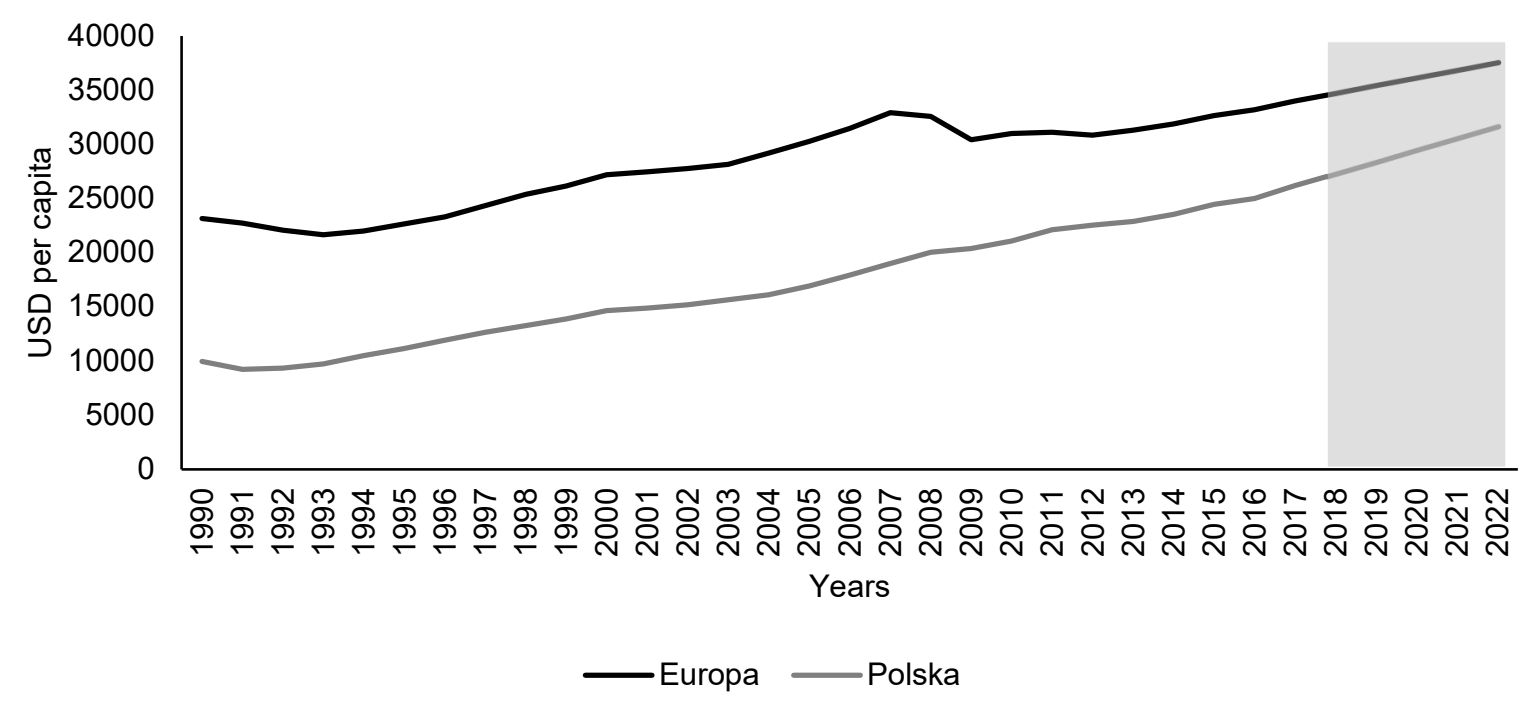

Fig. 7. Average value of the gross national income per capita for 42 European countries and Poland between 1990 and 2017 and their forecasts for 2018-2022

Source: author's own study based on the UNDP data.

The average gross national income per capita for the European countries concerned herein between 1990 and 2017 increased from USD 23,125.74 to USD 33,987.33, i.e. by $47.0 \%$. The clear fluctuation identified in its historical data correspond to the global economic crisis. For Poland, the level of this component was distinctly lower that the European mean value, while it rose from USD 9,935 to 26,150 , which is by $263.21 \%$.

In 2022, the average value of gross national income per capita for the studied countries should reach USD $37,494.49$, which will mark a growth of $10.3 \%$ from 2017 . For Poland, this variable should increase by $20.9 \%$, i.e. to reach USD $31,607.85$. Figure 8 presents, in a non-decreasing order, European countries according to their values of gross national income per capita in 2017 and the forecasts for 2022. 


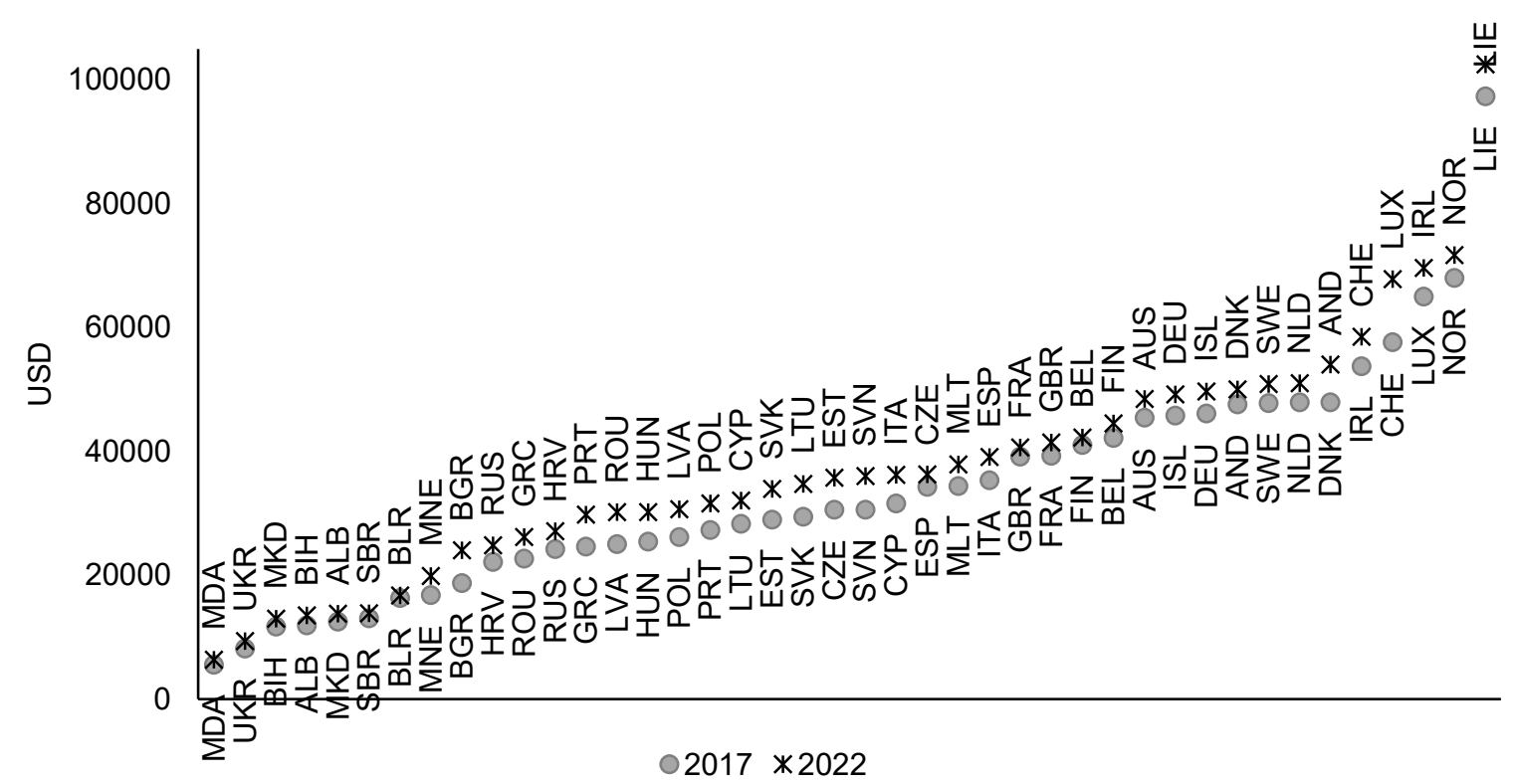

Fig. 8. European countries according to their values of gross national income per capita in 2017 and the forecasts for 2022.

Source: author's own study based on the UNDP data.

The highest level of the fourth HDI component in 2017 was demonstrated by Lichtenstein (USD 97,336), whose measured income level was more than $40 \%$ higher than that of the runners-up, Norway (USD 68,012) and Luxemburg (USD 65,016). The lowest value of the gross national income component was observed for Moldavia (USD 5,554). Here, Poland ranked $27^{\text {th }}$ with a gross national income of USD 26,150 .

An analysis of the forecasts for 2022 shows that the highest value of gross national income per capita, similarly to 2017 , will be achieved by Lichtenstein, and it is expected to exceed USD 100 thous. per person (USD 102,467.20), increasing by approx. 5.27\% from 2017. The second-ranking Norway had a forecast value of this component of over $30 \%$ less than that for Lichtenstein (USD 71,691.45). The lowest value of gross national income per capita was again anticipated for Moldavia (USD 6,343.77).

A comparison of the forecast of gross national income per capita for 2022 and the measurement for 2017 indicates that the highest growth should be enjoyed by Romania $(33.14 \%)$, Ireland (29.6\%) and Bulgaria (28.1\%), while Belgium is expected to increase the least $(0.2 \%)$.

\section{CONCLUSIONS}

The aforementioned analyses depict Europe as characterized by stable development. Between 1990 and 2017, all the four HDI components were clearly increasing. This trend should be maintained in the period from 2018 to 2022, as well. However, a closer analysis indicates that Europe is clearly divided into two zones - the East and the West.

In the case of two of the components (life expectancy and gross national income per capita), Poland plainly falls behind the European average. Nevertheless, as suggested by our analysis of the pace at which these components have been changing, this country is catching up. In the case of the two other components, Poland exceeds the European mean values decidedly, and the dynamics of the processes observed indicate that it will keep doing so. 


\section{REFERENCES}

Anand S., Sen A.K. 1994. Human Development Index: Methodology and Measurement. Human Development Report Office: Occasional Papers, 1-14.

European Commission. 2019. European Economic Forecast, institutional paper 102 https://ec.europa.eu/info/sites/info/files/economy-finance/ip102_en.pdf.

Eurostat. 2018. Causes of death statistics. http://ec.europa.eu/eurostat/statistics-explained/index.php/ /Causes_of_death_statistics, access: 20.10.2019.

Foreman K.J., Marquez N., Dolgert A., Fukutaki K., Fullman N., McGaughey M., Pletcher M.A., Smith A.E., Tang K., Yuan Ch., Brown J.C., Friedman J., He J., Heuton K.R., Holmberg M., Patel D.J., Reidy P., Carter A., Cercy K., Chapin A., Douwes-Schultz D., Frank T., Goettsch F., Liu P.Y., Nandakumar V., Reitsma M.B., Reuter V., Sadat N., Sorensen R.J.D., Srinivasan V., Updike R.L., York H., Lopez A. D., Lozano R., Lim S.S., Mokdad A.H., Vollset S.E., Murray Ch.J.L. 2018. Forecasting life expectancy, years of life lost, and all-cause and cause-specific mortality for 250 causes of death: reference and alternative scenarios for 2016-40 for 195 countries and territories. Lancet, 392(10159), 2052-2090. DOI: 10.1016/S0140-6736(18)31694-5, access: 10.10.2019.

GUS. 2014. Population Projection 2014-2050. Warsaw: Statistical analysis and studies. https://stat.gov.pl/ /download/gfx/portalinformacyjny/en/defaultaktualnosci/3287/2/5/1/p_population_projection_for_pol and_2014_2050.pdf, access: 14.07.2019.

Holt C.H. 2004. Forecasting seasonals and trends by exponentially weighted moving averages. International J. Forecasting, 20(1), 5-10. https://doi.org/10.1016/j.ijforecast.2003.09.015, access: 10.10.2019.

Kontis V., Bennett J.E., Mathers C., Li G., Foreman K., Ezzati M. 2017. Future life expectancy in 35 industrialised countries: projections with a Bayesian model ensemble. The Lancet, 389(10076), 1323-1335. doi: 10.1016/S0140-6736(16)32381-9, access: 10.10.2019.

Lee R. 2003. Mortality Forecasts and Linear Life Expectancy Trends. In T. Bengtsson (Ed.), Perspectives on Mortality Forecasting. III. The Linear Rise in Life Expectancy: History and Prospects, (19-39). Stockholm: Försäkringskassan, Swedish Social Insurance Agency.

OECD. 2012. Eurostat-OECD Methodological Manual on Purchasing Power Parities. Luxembourg: Publications Office of the European Union. https://www.oecd-ilibrary.org/eurostat-oecd-methodological-manual-on-purchasing-power-parities_5k8zpst7wxnv.pdf?itemld=\%2Fcontent\%2Fpublication\% 2F9789264189232-en\&mimeType=pdf, access: 28.10.2019.

Raczkowska M. 2016. Jakość życia w krajach Unii Europejskiej [Quality of life in the European Union]. Pr. Nauk. Uniw. Ekon. Wroc. 449, 511-521. [in Polish]

Stanton E.A. 2007. The Human Development Index: A History. Political Economy Research Institute Working Papers, 127. https://scholarworks.umass.edu/cgi/viewcontent.cgi?article=1101\&context= =peri_workingpapers, access: 12.08.2019.

Torri T., Vaupel J.W. 2012. Forecasting life expectancy in an international context. International Journal of Forecasting, 28(2), 519-531. doi: doi.org/10.1016/j.jforecast.2011.01.009, access: 26.10.2019.

UNPD. 2017. Human Development Report 2016 - Technical notes. Retrieved from http://hdr.undp.org/ /sites/default/files/hdr2016_technical_notes.pdf, access: 2.07.2019.

Zeliaś A., Pawełek B., Wanat, S. 2003. Prognozowanie ekonomiczne. Teoria, przykłady, zadania. Warszawa, Wydaw. Nauk. PWN. [in Polish]

\section{PROGNOZA WARTOŚCI SKŁADOWYCH WSKAŹNIKA HDI DLA KRAJÓW EUROPY NA LATA 2018-2022}

Streszczenie. W artykule przedstawiano prognozy wartości czterech składowych wskaźnika rozwoju społecznego, dotyczących trzech sfer życia: zdrowia, edukacji oraz dochodów, dla 42 krajów Europy na lata 2018-2022, ze szczególnym uwzględnieniem Polski. Do ich wyznaczenia 
wykorzystano model Holta. Uzyskane wyniki sugerują dalszą poprawę sytuacji społeczno-ekonomicznej w większości analizowanych krajów. Dane statystyczne wykorzystane w pracy pochodziły z raportów Human Development Report. Obliczenia wykonano w pakiecie R.

Słowa kluczowe: składowe indeksu HDI, prognozy, Europa, Polska. 